\title{
The Effectiveness of Predict Observe Explain (POE) Model with PhET to Improve Critical Thinking Skills of Senior High School Students
}

\author{
*I F Alfiyanti ${ }^{1}$, B Jatmiko², Wasis ${ }^{2}$ \\ 1Science Education Study Program, Postgraduate Program, Universitas Negeri Surabaya, Surabaya 60231, Indonesia \\ 2Science Education Study Program, Doctoral Program, Universitas Negeri Surabaya, Surabaya 60231, Indonesia
}

\begin{tabular}{|c|c|}
\hline Article Info & ABSTRACT \\
\hline Article history: & \multirow{7}{*}{$\begin{array}{l}\text { This study is aimed to determine the effectiveness of predict observe } \\
\text { explain (POE) model with PhET to improve critical thinking skills of } \\
\text { Senior High School students. The sample used was the grade eleven } \\
\text { students of SMA N } 18 \text { Surabaya consist of } 60 \text { students. This type of } \\
\text { research was pre-experimental with one group pre-test post-test } \\
\text { design. Research data is obtained from the result of pre-test and post- } \\
\text { test of students' critical thinking skills and responses after learning } \\
\text { activity. Data analysis techniques used N-gain and Wilcoxon test. } \\
\text { The result of the study shows that the score of students' critical } \\
\text { thinking skills in grade eleven of Group } 1 \text { and Group } 2 \text { increase after } \\
\text { the implementation of predict observe explain (POE) learning model } \\
\text { with PhET and both of them present positive responses to the } \\
\text { learning component and show a good interest. Based on the data } \\
\text { analysis result, it can be concluded that predict observe explain } \\
\text { (POE) model with PhET is effective to use to improve the critical } \\
\text { thinking skills of Senior High School students. }\end{array}$} \\
\hline $\begin{array}{l}\text { Received July, } 142020 \\
\text { Revised August, } 172020 \\
\text { Accepted August, } 242020 \\
\text { Available Online August, } 312020\end{array}$ & \\
\hline & \\
\hline POE Model & \\
\hline & \\
\hline $\begin{array}{l}\text { Critical Thinking } \\
\text { Student Responses }\end{array}$ & \\
\hline Senior High School & \\
\hline
\end{tabular}

https://doi.org/10.46627/silet

\section{INTRODUCTION}

Physics is considered important to be taught for students because it provides knowledge. Physics is also a mean or vehicle to grow thinking skills that are useful for solving problems in everyday life. The developed thinking skills are basic skills to higher level thinking skills. One of the high level thinking skills is critical thinking skill. Critical thinking is a skill to examine the knowledge or thing that is believed based on supporting evidence (Wahyuni, 2015). According to Fahim \& Pezeshki (2012), critical thinking is a competency needed in student life. Slavin (2011) explains that critical thinking skill does not come alone but it needs to be familiarized and trained. This explanation is in accordance with the theory of constructivism. In constructivism, teachers do not only provide knowledge to students but also give opportunities for students to find their own ideas. But in fact, the lack of students' critical thinking skills is found both in national and international education. Based on several studies in Indonesia, this evidence is found in a result of research by Saputri (2019) in Surakarta, Hairida (2016) in Pontianak, and Mahanal et al., (2016) in Malang. Whereas international research conducted by Teleb \& Chadwick (2016) in Dubai and Changwong, Sukkamart, \& Sisan (2018) in Thailand also shows that students' critical thinking skills in countries all over the world is classified as low. The low critical thinking skill of students in Indonesia can also be seen on the result of the Program for international student assessment (PISA).

PISA research to test scientific literacy that is closely related to higher order thinking skills shows that the results of PISA 2018, Indonesia is ranked 74 out of 79 countries. In the field of 
science, Indonesia obtained a score of 396 from an OECD average score of 489 and around $40 \%$ of Indonesian students reached level 2, whereas the OECD average was 78\%. As for level 2 in

science ability, it means that students are still able to recognize the correct explanation for known scientific phenomena and can use that knowledge to identify in simple cases (OECD, 2019). This shows that Indonesian students are still not fully trained to do critical thinking, resulting to the bottom position and is generally still below the average score for the Organization for Economic, Cooperation and Development (OECD) (Suprapto, 2016).

Based on the Field Experience Program (PPL) conducted by researchers at SMA N 18 Surabaya by applying student activity sheets critical thinking skills on dynamic material, it showed that the student's average score was still below 76. It means that students still have difficulties to interpret data, analyze, evaluate, and conclude experimental results. Moreover, the result of interview with students show that students have low interest in physics and are less active in the learning process in class. They think that physics is a difficult subject and identical to memorize systematic equations or formulas. This results in problems such as the high quantity of physics misconceptions and lack of students' ability to criticize problems in physics. Therefore, necessary condition for an interactive learning environment where students are actively involved in learning process, so they are accustomed to and trained in critical thinking. One of them is by choosing the appropriate learning approach or model.

One learning model that can give opportunities for students to be actively involved and practice critical thinking is the predict observe explain (POE) learning model. This learning model involves students in predicting a phenomenon, observing through experiments, and explaining the suitability of prediction with the experiment result. So, POE model is effective for obtaining and increasing students' critical thinking in science.

According to Ulfah, Asim, \& Parno (2014), the learning model of POE (Predict Observe Explain) can improve critical thinking skills and students' motivation because each step of the learning process contains learning activities that guide students actively in the learning process. Based on research conducted by Yulianti (2012), learning model of POE (Predict Observe Explain) can improve students' critical thinking skills and mastery of student concepts. besides, according to Ayvaci (2013) by learning to use the POE model, students are more interested in learning concepts.

The POE learning model has three stages: 1) Predict, 2) Observe, 3) Explain (Cinici \& Demir, 2013). The beginning stage aims to reveal the conception profile of students. While the second and third stages, students go through an accommodation process where students have the opportunity to experience changes in concepts and strengthen new concepts obtained by students from the previous stage.

Agustina, Yushardi, \& Lesmono (2018) states that kinetic theory of gases is an abstract material and cannot be observed directly, where students cannot learn the properties of gases based on the behavior of the atoms of gases that move randomly. Moreover, there are no devices that support experiment activity related to the kinetic theory of gases. Therefore, using a virtual laboratory is very possible. A virtual laboratory is a laboratory used in the simulation to display the process of experimentation. One of the virtual laboratories that are usually used to understand abstract physics concepts is virtual laboratory Physic Education Technology (PhET). PhET simulation is a virtual learning media that displays natural phenomena and is equipped with a simple experiment that can help users understand concepts (Prima, Putri, \& Rustaman, 2018).

Based on research conducted by Taqwa \& Putra (2017), they declared that the use of the POE model is able to stimulate students to understand existing concepts and with the PhET learning media, students can conduct research on abstract material. The research of Salame \& Samson (2019), shows that learning with PhET media has positive impacts on student attitude, contributes to the learning experience, and increases students' involvement in the learning process. And in the research conducted by Ferty, Wilujeng \& Kuswanto (2019), the obtained 
result shows that the scaffolding approach model with Physic Education Technology (PhET) can improve students' critical thinking skills.

In a previous study by Awalia, Sitompul, \& Hamdani (2016) that POE was able to reduce student misconceptions by $46.8 \%$. It was also found that student learning experiences are stored in long term memory. Therefore, stimulation is needed in overcoming the problem. To train students' critical thinking skills, researchers feel that we were needed to use approaches that can engage students actively in learning and motivate students more to learn so that the learning process feels fun. POE is assumed to fulfill these demands. This can be seen from the POE model that provides opportunities for students to predict, observe problems, and explain the problem. However, the POE Model that introduces virtual laboratory facilities does not yet exist. Whereas in this day and age, learning activities can take advantage of the availability of existing technology, using virtual laboratories that are assisted by PhET media, which allows students to connect real-life phenomena and the underlying science to facilitate students to understand abstract material such as kinetic gas theory.

Learning physics with a virtual laboratory Physics Education Technology (PhET) does not require much time in implementation if it is compared to using a real laboratory, so teachers can still complete the material in time and students can do the experiment in accordance with the demand of the curriculum 2013.

Based on the description of the problems above, the problem formulation of this study is as follows: how is the effectiveness of the POE model with PhET to improve critical thinking skills of senior high school students?

\section{RESEARCH METHOD}

This study use the POE learning model with PhET to improve critical thinking skills of Senior High School students. This type of research is pre-experimental with one group pre-test post-test research design. The research design is shown in Figure 1.

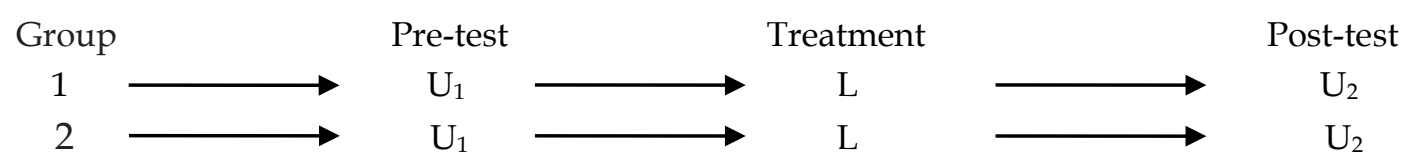

Figure 1. Research design

(Prabowo, 2011)

Explanation:

$\mathrm{U}_{1}=$ Pre-test, to determine the ability of students before being given the treatment

$\mathrm{L}=$ Treatment, learning process using the POE model with PhET

$\mathrm{U}_{2}=$ Post-test, to determine the ability of students after being given the treatment

The research sample was grade eleven of Group 1 and Group 2 in SMA Negeri 18 Surabaya consists of 60 students. The sample was determined by using the purposive sampling technique. The time of the implementation was in the 2019/2020 school year. Learning materials that support the learning process was Syllabus, Lesson Plan (RPP), Student's Textbook, Student activity sheet, critical thinking skills test, and assessment rubric. To determine the students' responses, the response sheet is used. Meanwhile, to determine students' critical thinking skills, the test technique (pre-test and post-test) is performed. The test instrument used was 7 items description of the kinetic theory of gases and the question was validated by the experts. The result of students' critical thinking skills was analyzed using the N-gain test and Wilcoxon signed-rank test (Rostina, 2014). 


\section{RESULTS AND DISCUSSION}

\section{Students' Critical Thinking Skills}

Critical thinking skills tests give to students before learning (pre-test) and after learning using POE model with PhET (post-test). The pre-test score in grade eleven of Group 1 shows that all students had not yet completed, while in the post-test score 13 students had not yet completed and 17 students had achieved the minimum completeness criteria. In grade eleven of Group 1, the pre-test score of all students was not yet complete, while in the post-test score 11 students were not yet finished and 19 students had achieved the minimum completeness criteria.

The average pre-test score of critical thinking skills achieved students of grade eleven of Group 2 is still low at 33 and for the post-test average score of 78 from the maximum completeness of 100. Likewise for the average pretest score achieved students grade eleven of Group 2 is still low at 27 and for the average post-test score is 79 from the maximum completeness 100. It shows difference in students' pre-test and post-test score. The post-test score was higher than the post-test. The difference of the score happened because learning using PhET media, the students can directly observe the gases movement and connect the experiment result with daily-life phenomena given by the teacher, so it can train students' critical thinking skills (Kapelle et al., 2019). In the learning process, students were asked to explain the prediction congruence and the experiment result. It will make students easier to remember the concepts that have been learned. In line with the research conducted by Rini, Suryani, \& Fadhilah (2018) shows the average score of students who use the POE model is higher than those who do not use it. Then to determine the indicator completeness of students' critical thinking skills is shown in Table 1.

Table 1. Completeness of Students' Critical Thinking Skills

\begin{tabular}{lcccccccc}
\hline $\begin{array}{c}\text { Indicators of } \\
\text { critical } \\
\text { thinking skills }\end{array}$ & $\begin{array}{c}\text { Pre- } \\
\text { test }\end{array}$ & Category & $\begin{array}{c}\text { Post- } \\
\text { test } \boldsymbol{t}\end{array}$ & Category & $\begin{array}{c}\text { Pre- } \\
\text { test } \boldsymbol{t}\end{array}$ & Category & $\begin{array}{c}\text { Post- } \\
\text { test } \boldsymbol{t}\end{array}$ & Category \\
\hline Explanation & 31 & Incomplete & 78 & Complete & 30 & Incomplete & 78 & Complete \\
Analysis & 52 & Incomplete & 83 & Complete & 43 & Incomplete & 81 & Complete \\
Interpretation & 31 & Incomplete & 78 & Complete & 24 & Incomplete & 83 & Complete \\
Inference & 33 & Incomplete & 76 & Complete & 23 & Incomplete & 76 & Complete \\
Evaluation & 21 & Incomplete & 78 & Complete & 19 & Incomplete & 79 & Complete \\
\hline
\end{tabular}

Indicators of critical thinking skills measured are interpretation, evaluation, explanation, inference, and analysis (Facione, 2011). Table 1 shows the average indicators of students' critical thinking skills in the pre-test scores are incomplete categories for each indicator, while in the post-test scores are obtained complete categories for each indicator. It has happened because by using the POE model, students must be actively involved in the learning process by having discussions with friends and teachers so that students will better understand the material being taught. This is in line with the research conducted by (Banawi et al., 2019; Teo, Yan, \& Goh, 2016; Adibayo \& Olufunke, 2015; Akpinar, 2014; Chang et al., 2013; Hsu, Tsai, \& Liang, 2011) which shows that the POE learning model can improve student comprehension, in addition according to the research (Karamustafaoglu \& Mamlok-Naaman, 2015), using the POE learning model obtained post-score tests that experience significant changes, have fewer misunderstandings and the average of the post-test scores learning with the POE model is better than teacher-centered learning (Kibirige, Osodo, \& Tlala, 2014; Hilario, 2015). In addition, the experiment using PhET media is more fun, because PhET media is equipped with simple experiments that make it easier for students to learn and play in the simulation. PhET learning media can also educate students to have a constructivist mindset, where students can combine initial knowledge with virtual findings from PhET simulation that is run. This is in accordance with the expression of Ramadan \& Astuti (2020) that students think more critically in learning using PhET media. 
The enhancement of students' critical thinking skills from the results of pre-test and posttest that has been done in two groups then measured by using the n-gain score analysis. N-gain of students' pre-test and post-test of critical thinking skills in grade eleven of Group 1 obtained an average score which is 0.67 with medium category and the N-gain results of grade eleven of Group 2 is 0.71 with high category. There is a difference of N-gain in grade eleven of Group 1 and grade eleven of Group 2, because in grade eleven of Group 1 some students have less attention to the explanation from the teacher during the learning process. The guideline to determine the $\mathrm{N}$-gain results categorized as medium or high, according to the opinion of (Hake, 2004) which states that the value of $\mathrm{N}$-gain is categorized as high if obtaining an N-gain result $>0.70$, medium category if obtaining $0.30 \leq \mathrm{N}$-gain $\leq 0.70$, and categorized as low if $\mathrm{N}$ gain results $<0.30$. The number of students who get $\mathrm{N}$-gain groups with high, medium, and low categories in both groups are presented in Figure 2.



Figure 2. Graph of N-gain Accomplishment Criteria

Figure 2 shows that in grade eleven of Group 1 there are 14 high category students, 14 medium category students, and 2 low category students. Furthermore, grade eleven of Group 2 consisted of 18 students with high category, 11 students with medium category, and 1 student with low category. The difference in the average results of students' $\mathrm{N}$-gain score is influenced by several factors including the student's comprehension of the kinetic theory of gases, the difficulty level of the questions, and the question forms. The test used in this study is essay question, because it is usually used in physics subjects. This is in line with the opinion of Widoyoko (2015) who said that the form of essay question was used on subjects with clear boundaries, such as physics, mathematics, chemistry, and biology. The questions in this test only have one answer, which is started by choosing the right formula, inputting numbers in the formula, then calculating, and interpreting the results. Besides, the essay question is also widely used to measure higher abilities in the area of knowledge, such as using, analyzing, assessing, and thinking creatively because through this type of test students are invited to explain, compare, create and assess an evaluation object (Muri, 2015).

The normality test is then performed using SPSS version 22. The normality test results of N-gain data in grade eleven of Group 1 and grade eleven of Group 2 can be seen in Table 2.

Table 2. The Normality Test Results of N-gain Data

\begin{tabular}{|c|c|c|c|c|c|c|c|c|}
\hline \multirow{2}{*}{ Group } & \multicolumn{3}{|c|}{ Kolmogorov-Smirnov ${ }^{a}$} & \multicolumn{3}{|c|}{ Shapiro-wilk } & \multirow{2}{*}{ Analysis } & \multirow{2}{*}{ Conclusion } \\
\hline & statictic & $\mathrm{df}$ & $p$ & statictic & $\mathrm{df}$ & $p$ & & \\
\hline $\begin{array}{l}\text { Grade eleven of } \\
\text { Group } 1\end{array}$ & .127 & 30 & .200 & .866 & 30 & .001 & $0.001>0.05$ & $\begin{array}{l}\text { Not normally } \\
\text { distributed }\end{array}$ \\
\hline $\begin{array}{c}\text { Grade eleven of } \\
\text { Group } 2\end{array}$ & .133 & 30 & .187 & .874 & 30 & .002 & $0.002>0.05$ & $\begin{array}{c}\text { Not normally } \\
\text { distributed }\end{array}$ \\
\hline
\end{tabular}

Table 2 shows that the N-gain score of grades eleven of Group 1 and grade eleven of Group 2 obtains p-values $<0.05$. This can be said that $\mathrm{H}_{0}$ is rejected, which means it is not normally 
distributed. Because the data obtained are not normally distributed, the statistical test used is the Wilcoxon signed-rank test. The results of the Wilcoxon signed-rank test are shown in Table 3.

Table 3. The Wilcoxon Signed-Rank Test Result of Pre-Test and Post-Test Score

\begin{tabular}{|c|c|c|c|c|c|}
\hline Group & Mean & Std. Deviation & $\mathrm{Z}$ & $\mathrm{P}$ (2-tailed) & Conclusion \\
\hline Grade eleven of Group 1 & $\begin{array}{r}.00 \\
15.50 \\
\end{array}$ & $\begin{array}{r}.00 \\
465.00 \\
\end{array}$ & $-4.788^{b}$ & 0.000 & $\mathrm{H}_{0}$ is rejected \\
\hline Grade eleven of Group 2 & $\begin{array}{r}.00 \\
15.50\end{array}$ & $\begin{array}{r}.00 \\
465.00\end{array}$ & $-4.793^{b}$ & 0.000 & $\mathrm{H}_{0}$ is rejected \\
\hline
\end{tabular}

The Wilcoxon signed-rank test is used to find out the improvement of students' critical thinking skills by using pre-test and post-test scores of each group. The improvement of students' critical thinking skills showed in Table 3 using pre-test and post-test scores in grade eleven of Group 1 and grade eleven of Group 2 obtained p-values $<0.05$. It can be said that $\mathrm{H}_{0}$ is rejected, so there is a significant increase after the learning process with the POE model with PhET. This is in accordance with the research conducted by Furqani, Feranie, \& Winarno (2018) which shows that by using the POE learning model, the students' comprehension and critical thinking skills have increased. The improvement in student test scores is supported by the opinion of Vygotsky that cognitive changes in students occur if concepts that have been previously understood are processed through an imbalance stage to learn new information. Besides that, using PhET learning media can make student performance better and increase student involvement (Ganasen \& Shamuganathan, 2017).

\section{Students' Response}

The effectiveness of learning process using POE model with PhET media can also be viewed from student responses. The data of student response result is obtained through a questionnaire filled out by students after all learning activities. The response questionnaire consisted of 16 assessment aspects. The results of student responses are presented in Table 4.

Table 4. Results of student responses

\begin{tabular}{|c|c|c|c|c|}
\hline \multirow{3}{*}{ Aspects } & \multicolumn{4}{|c|}{ Student Responses } \\
\hline & \multicolumn{2}{|c|}{$\begin{array}{l}\text { Grade eleven } \\
\text { of Group } 1 \\
\end{array}$} & \multicolumn{2}{|c|}{$\begin{array}{l}\text { Grade eleven of } \\
\text { Group } 2\end{array}$} \\
\hline & Yes & No & Yes & No \\
\hline The POE learning model with PhET is interesting and fun & 100.00 & 0.00 & 100.00 & 0.00 \\
\hline I am more active in POE learning model with PhET & 96.67 & 3.33 & 96.67 & 3.33 \\
\hline $\begin{array}{l}\text { I am more motivated in POE learning model with PhET to } \\
\text { improve critical thinking skills }\end{array}$ & 93.33 & 6.67 & 93.33 & 6.67 \\
\hline $\begin{array}{l}\text { The POE learning model with PhET takes place very } \\
\text { systematically and clearly }\end{array}$ & 90.00 & 10.00 & 93.33 & 6.67 \\
\hline The POE learning model with PhET is new to me & 80.00 & 20.00 & 53.33 & 46.67 \\
\hline $\begin{array}{l}\text { The instructions given by teacher during the learning process } \\
\text { and doing the worksheet are very clear and useful }\end{array}$ & 9.33 & 6.67 & 100.00 & 0.00 \\
\hline $\begin{array}{l}\text { By working in groups, I can more easily study and discuss with } \\
\text { my friends while doing the student activity sheet and more } \\
\text { easily understand when formulating problems, making } \\
\text { hypotheses, collecting data, analyzing and making conclusions. }\end{array}$ & 96.67 & 3.33 & 100.00 & 0.00 \\
\hline The learning process triggers my curiosity & 100.00 & 0.00 & 96.67 & 3.33 \\
\hline $\begin{array}{l}\text { The learning materials (student's textbook), The learning } \\
\text { atmosphere, the way the teacher teaches and the stages directed } \\
\text { at learning process are very new and interesting to me }\end{array}$ & 86.67 & 13.33 & 96.67 & 3.33 \\
\hline The learning process that has been done makes me better & 100.00 & 0.00 & 96.67 & 3.33 \\
\hline
\end{tabular}




\begin{tabular}{|c|c|c|c|c|}
\hline \multirow{3}{*}{ Aspects } & \multicolumn{4}{|c|}{ Student Responses } \\
\hline & \multicolumn{2}{|c|}{$\begin{array}{l}\text { Grade eleven } \\
\text { of Group } 1\end{array}$} & \multicolumn{2}{|c|}{$\begin{array}{l}\text { Grade eleven of } \\
\text { Group } 2\end{array}$} \\
\hline & Yes & No & Yes & No \\
\hline \multicolumn{5}{|l|}{ understand the kinetic theory of gases } \\
\hline $\begin{array}{l}\text { Learning physics using the POE learning model with PhET } \\
\text { allows me to improve my critical thinking skills }\end{array}$ & 93.33 & 6.67 & 96.67 & 3.33 \\
\hline $\begin{array}{l}\text { I am happy to implement the POE learning model that are } \\
\text { equipped with practical activities using the PhET media }\end{array}$ & 100.00 & 0.00 & 93.33 & 6.67 \\
\hline $\begin{array}{l}\text { The teacher gives explanations that are easily to be understood } \\
\text { during the learning process }\end{array}$ & 96.67 & 3.33 & 100.00 & 0.00 \\
\hline $\begin{array}{l}\text { Learning material associated with daily life so that makes me } \\
\text { happy and better understand the application of the kinetic } \\
\text { theory of gases in daily life }\end{array}$ & 96.67 & 3.33 & 100.00 & 0.00 \\
\hline $\begin{array}{l}\text { The questions given is appropriate with the theory that has been } \\
\text { taught }\end{array}$ & 100.00 & 0.00 & 100.00 & 0.00 \\
\hline $\begin{array}{l}\text { I am interested to participate in learning process as has been } \\
\text { done now in the next learning activities }\end{array}$ & 96.67 & 3.33 & 86.67 & 13.33 \\
\hline The Percentage of Average & 95.00 & 5.00 & 94.00 & 6.04 \\
\hline Category & \multicolumn{2}{|c|}{ Positive } & \multicolumn{2}{|c|}{ Positive } \\
\hline
\end{tabular}

From Table 4, it is known that grade eleven of Group 1 obtained a percentage of $95 \%$ and grade eleven of Group 2 amounted to $94 \%$ which means students gave a positive response to the POE learning model with PhET. This is in line with a research by Nana, Akhyar, \& Rochsantiningsih (2014) which states that students have a positive attitude towards learning, besides the POE learning model will make students more interested in learning science concepts and with PhET provides a unique tool that makes learning more effective and more fun (Wieman et al., 2010).

Both groups gave a response that the learning process by using POE model with PhET media can train students to think critically. This is because at the beginning of learning students are asked to predict a phenomenon related to daily life so that it can stimulate students to think critically (Hermita et al, 2019). In the experimental activities, students conducted experiments with PhET media. PhET media can help students to observe direct experiments on abstract subject matter such as the kinetic theory of gases. Conducting experiments with PhET can increase student involvement in learning activities. This can be observed from the enthusiasm of students to ask questions if they have difficulty conducting experiments. Then students discuss the results of the experiment and match the predicted results. Through discussion activities students not only receive information from others but students must build their own knowledge by linking the information obtained through experimental activities.

According to Panjaitan, Nur, \& Jatmiko (2015), another factor influencing student responses to classroom learning is the relationship between teachers and students. Students who feel close to the teacher will tend to play an active role in classroom learning activities. To build a good relationship with students, the teacher's way of speaking and acting must reflect as a teacher who respects and accepts the situation of students. The teacher must also ensure that each student gets the same treatment. So that students during the learning process give a positive response to the activities and updating the learning model carried out in class.

\section{CONCLUSION}

Based on the research results, it shows that POE model with PhET effective to improve critical thinking skills of Senior High School students. It is showed from the result of the completeness five indicators of critical thinking skills after learning and the post-test scores are higher than the pre-test scores, which means there is increase in students' critical thinking skills. Besides, both groups give positive responses to the learning process. The research implication is that 
POE model with PhET is successful to improve critical thinking skills. POE learning model with PhET can involve students actively in learning so it will be easier to understand the material taught. Further research should conduct research about critical thinking skills on different subject matter and subjects.

\section{ACKNOWLEDGEMENTS}

The author would like to thank SMA Negeri 18 Surabaya students, especially grade eleven of Group 1 and Group 2 who are willing to be the sample in my research.

\section{REFERENCES}

Adibayo, F., \& Olufunke, B. T. (2015). Generative and predict-observe-explain instructional strategies; towards enhacing basic science practical skills of lower primary school pupils. International Journal of Elementary Education, 4(4), 86-92.

Agustina, M., Yushardi, Y., \& Lesmono, A. D. (2018). Analisis Penguasaan Konsep-Konsep Teori Kinetik Gas Menggunakan Taksonomi Bloom Berbasis Hots Pada Siswa Kelas Xi Ipa Di Man Jember. Jurnal Pembelajaran Fisika, 7(4), 334-340.

Akpinar, E. (2014). The use of interactive computer animations based on POE as a presentation tool in primary science teaching. Journal of Science Education and Technology, 23(4), 527-537.

Ayvac1, H. Ş. (2013). Investigating the effectiveness of predict-observe-explain strategy on teaching photo electricity topic. Journal of Baltic Science Education, 12(5), 548.

Awalia, V., Sitompul, S. S., \& Hamdani, H. (2016). Remediasi Miskonsepsi Peserta Didik SMP Tentang Cermin Datar Menggunakan Strategi Prediction, observation, And Explanation. Jurnal Pendidikan dan Pembelajaran Khatulistiwa, 5(6), 1-14.

Banawi, A., Sopandi, W., Kadarohman, A., \& Solehuddin, M. (2019). Prospective Primary School Teachers' Conception Change on States of Matter and Their Changes through Predict-Observe-Explain Strategy. International Journal of Instruction, 12(3), 359-374.

Chang, J. L., Chen, C. C., Tsai, C. H., Chen, Y. C., Chou, M. H., \& Chang, L. C. (2013). Probing and Fostering Students' Reasoning Abilities with a Cyclic Predict-Observe-Explain Strategy. In Chemistry Education and Sustainability in the Global Age, 49-57.

Changwong, K., Sukkamart, A., \& Sisan, B. (2018). Critical thinking skill development: Analysis of a new learning management model for Thai high schools. Journal of International Studies, 11(2), 37-48

Cinici, A., \& Demir, Y. (2013). Teaching through cooperative POE tasks: A path to conceptual change. The Clearing House: A Journal of Educational Strategies, Issues and Ideas, 86(1), 1-10.

Facione, P. A. (2011). Critical thinking: What it is and why it counts. Insight assessment, 2007(1), $1-23$.

Fahim, M., \& Pezeshki, M. (2012). Manipulating critical thinking skills in test taking. International Journal of Education, 4(1), 153.

Ferty, Z. N., Wilujeng, I., \& Kuswanto, H. (2019). Enhancing Students' Critical Thinking Skills through Physics Education Technology Simulation Assisted of Scaffolding Approach. In Journal of Physics: Conference Series, 1233(1), 012062.

Furqani, D., Feranie, S., \& Winarno, N. (2018). The Effect of Predict-Observe-Explain (POE) Strategy on Students' Conceptual Mastery and Critical Thinking in Learning Vibration and Wave. Journal of science learning, 2(1), 1-8.

Ganasen, S., \& Shamuganathan, S. (2017). The effectiveness of physics education technology (PhET) interactive simulations in enhancing matriculation students' understanding of chemical equilibrium and remediating their misconceptions. In Overcoming students' misconceptions in science, 157-178.

Hairida, H. (2016). The effectiveness using inquiry based natural science module with authentic assessment to improve the critical thinking and inquiry skills of junior high school students. Jurnal Pendidikan IPA Indonesia, 5(2), 209-215. 
Hake, R. (2004). Design-based research: A primer for physics-education researchers. American Journal of Physics, 1-35.

Hermita, N., Dewi, R., Alpusari, M., Noviana, E., Kurniaman, O., Antosa, Z., \& Putra, E. D. (2019). Improvement of elementary school critical thinking skills through the POE learning model (predict-observe-explain) on natural resource material. Journal of Physics: Conference Series, 1351(1). https:/ / doi.org/10.1088/1742-6596/1351/1/012076

Hilario, J. S. (2015). The use of Predict-Observe-Explain-Explore (POEE) as a new teaching strategy in general chemistry laboratory. International Journal of Education and Research, 3(2),37-48.

Hsu, C. Y., Tsai, C. C., \& Liang, J. C. (2011). Facilitating preschoolers' scientific knowledge construction via computer games regarding light and shadow: The effect of the prediction-observation-explanation (POE) strategy. Journal of Science Education and Technology, 20(5), 482-493.

Kapelle, N. R., Jatmiko, B., Munasir, M., \& Wenno, I. H. (2019). Development of PhET-aid-based inquiry learning devices to improve student critical thinking skills. International Journal of Multicultural and Multireligious Understanding, 6(5), 980-990.

Karamustafaoğlu, S., \& Mamlok-Naaman, R. (2015). Understanding electrochemistry concepts using the predict-observe-explain strategy. Eurasia Journal of Mathematics, Science and Technology Education, 11(5), 923-936.

Kibirige, I., Osodo, J., \& Tlala, K. M. (2014). The effect of predict-observe-explain strategy on learners' misconceptions about dissolved salts. Mediterranean Journal of Social Sciences, 5(4), 300-310.

Mahanal, S., Zubaidah, S., Bahri, A., \& Dinnurriya, M. S. (2016). Improving students' critical thinking skills through Remap NHT in biology classroom. In Asia-Pacific Forum on Science Learning \& Teaching, 17(2), 1-19.

Muri, Y. (2015). Assesmen dan Evaluasi Pendidikan. Kencana.

Nana, S., Akhyar, M., \& Rochsantiningsih, D. (2014). The development of predict, observe, explain, elaborate, write, and evaluate (POE2WE) learning model in physics learning at senior secondary school. Development, 5(19), 56-65.

Organisation for Economic Co-operation and Development. (2019). Programme for international student assessment (PISA) results from PISA 2018. OECD Publishing.

Panjaitan, M. B., Nur, M., \& Jatmiko, B. (2015). Model pembelajaran sains berbasis proses kreatif-inkuiri untuk meningkatkan berpikir kreatif dan pemahaman konsep siswa SMP. Jurnal Pendidikan Fisika Indonesia, 11(1), 8-22.

Prabowo. (2011). Metodologi Penelitian (Sains dan Pendidikan Sains). Unesa University Press.

Prima, E., Putri, A. R., \& Rustaman, N. (2018). Learning solar system using PhET simulation to improve students' understanding and motivation. Journal of Science Learning, 1(2), 60-70.

Ramadan, E. M., \& Astuti, D. P. (2020). Application of e-handout based on PhET simulation to improve critical thinking skills and learning independence of high school students. Journal of Physics: Conference Series, 1440(1).

Rini, A. P., Suryani, N., \& Fadhilah, S. S. (2018). Development of predict observe explain (POE)based thematic teaching materials. Al-Ta lim Journal, 25(3), 206-215.

Rostina, S. (2014). Statistika Penelitian Pendidikan. Alfabeta.

Salame, I. I., \& Samson, D. (2019). Examining the implementation of PhET simulations into general chemistry laboratory. International Journal of Environmental and Science Education, 14(4), 207-217.

Saputri, A. C. (2019). Improving students' critical thinking skills in cell-metabolism learning using stimulating higher order thinking skills model. International Journal of Instruction, 12(1), 327-342.

Slavin, R.E. (2011). Educational psychology, theory and practice. Person Education. 
Suprapto, N. (2016). What should educational reform in Indonesia look like? - Learning from the PISA science scores of East-Asian countries and Singapore. Asia-Pacific Forum on Science Learning \& Teaching, 17(2), 1-21.

Taqwa, M. R. A., \& Putra, G. S. (2017). Kajian efektifitas penggunaan model POE berintegrasi PhET pada topik kelistrikan. Prosiding Seminar Nasional Pendidikan "NaNoDik", 42-52.

Teleb, H. M., \& Chadwick, C. (2016). Enhancing students critical thinking skill and analytical thinking skill at the higher education level in developing countries: Case study in Dubai. Journal of Education and Instructional Studies in the World, 6(1), 67-77.

Teo, T. W., Yan, Y. K., \& Goh, M. T. (2016). Using prediction-observation-explanation revision to structure young children's learning about floating and sinking. The Journal of Emergent Science, 10, 12-23.

Ulfah, Q. N., Asim, \& Parno. (2014). Penerapan model predict observe explain (POE) untuk meningkatkan kemampuan berpikir kritis siswa kelas XI MIA 4 SMAN 6 Malang dalam materi fisika kalor. Universitas Negeri Malang.

Wahyuni, S. (2015). Pengembangan petunjuk praktikum IPA untuk meningkatkan kemampuan berpikir kritis siswa SMP. Jurnal Pengajaran MIPA, 20(2), 196-203.

Widoyoko. (2015). Evaluasi progam pembelajaran: Panduan praktis bagi pendidik dan calon pendidik. Pustaka Pelajar.

Wieman, C. E., Adams, W. K., Loeblein, P., \& Perkins, K. K. (2010). Teaching physics using PhET simulations. The Physics Teacher, 48(4), 225-227.

Yulianti. (2012). Penerapan model pembelajaran POE (Predict Observe Explain) untuk meningkatkan penguasaan konsep dan berpikir kritis siswa pada subkonsep pencemaran air. Universitas Pendidikan Indonesia.

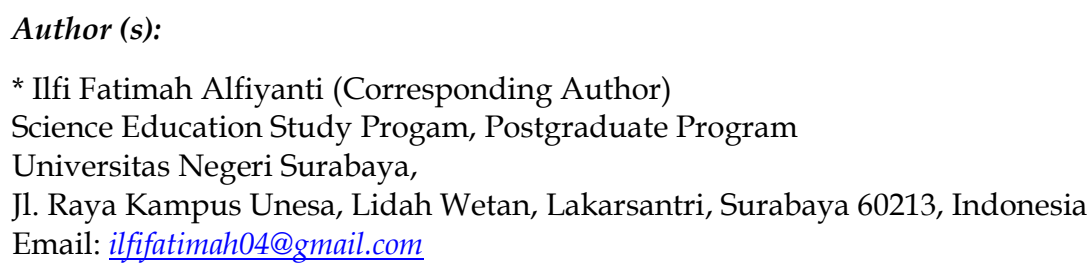

Budi Jatmiko

Science Education Study Progam, Doctoral Program

Universitas Negeri Surabaya,

Jl. Raya Kampus Unesa, Lidah Wetan, Lakarsantri, Surabaya 60213, Indonesia

Email: budijatmiko@unesa.ac.id

Wasis

Science Education Study Progam, Doctoral Program

Universitas Negeri Surabaya,

Jl. Raya Kampus Unesa, Lidah Wetan, Lakarsantri, Surabaya 60213, Indonesia

Email: wasis@unesa.ac.id 